\title{
THE ORCHIDACEAE OF ITACOLOMI STATE PARK IN MINAS GERAIS, BRAZIL
}

Ruy José Válka Alves ${ }^{1}$

Recebido em 15-8-89 Aceito em 15 5.90

RESUMO - Este trabalho faz uma parcial comparação de duas épocas da flórula de Orchidaceae do Parque Estadual do Itacolomi em Ouro Preto, MG. A primeira é representada por coletas anteriores a 1980, e a segunda pelas coletas dos últimos cinco anos. Análises florais documentam as coletas recentes.

Palavras-chave: Brasil, Florística, Minas Gerais, Orchidaceae, Ouro Preto.

ABSTRACT - This paper compares the partial Orchidaceae floras of Itacolomi State Park in Ouro Preto, Minas Gerais, Brazil, in two different periods. The first is represented by all colections prior to 1980 , while the second comprises those of the past five years. Floral analyses document the recent collections.

Key words: Floristic survey, Orchidaceae, Ouro Preto, Minas Gerais, Brazil.

\section{Introduction}

During the floristic survey of Itacolomi State Park above Ouro Preto in Minas Gerais, Brazil, (Figura 1), Marcos Peron had asked me to identify the collected orchid specimens and to make a list of species. To his specimens, I added those which I had collected during five recent expeditions. All specimens were then documented by slides for identification by the method of floral analysis (Alves 1989a).

Itacolomi State Park is a dolomite - quartzite formation reaching 1772 m.s.m. and is covered mainly by "cerrado" and "campo rupestre" types of vegetation. Saxicolous and epiphytic plants play an important role in these formations, which are dominated by a rather continuous herbaceous layer with sparse shrubs. Denser stands of woody plants occur only in places where the geomorphology permits accumulation of deeper and moister substrates (i.e. ventaroles etc.), and protects the locations from strong winds. Another factor which profoundly affects their occurence is anthropic management (frequent

1 - Czechoslovak Academy of Science. Botanical Institute. 25243 Pruhonice. Czechos lovakia. Bolsista de Doutorado do CNPq. 
-fires, overgrazing by cattle, etc.) The Orchidaceae that survive the combination of the above mentioned factors are of primary interest to my studies, and have been so for years.

\section{Material and Methods}

The species of Orchidaceae from Itacolomi State Park were studied both in the field and in herbaria. Flowered specimens were dried on standard herbarium sheets, part of their flowers having been fixed directly in $70 \%$ ethanol solution. Some sterile especimens were induced to flower in cultivation, and a few remain sterile to date. The environmental factors were recorded for most species. In order to avoid further reduction of the populations, many species were left in the field, (only two to four flowers were collected).

The identification of specimens was done according to the floral analysis method (Alves 1989a), or simply by comparison when posssible. Not all drughts here in are thus true analyses (Figure $2 \mathrm{~g}-\mathrm{k} ; 3 \mathrm{~g}-\mathrm{k}$ were drawn directly from the slide.) Transparent acetate slides of $24 \times 36 \mathrm{~mm}$ were used for most species. For the Epidendrum ellipticum sp. agg., only the labellum structures are necessary. For some genera other taxonomically relevant structures were draw, such as the column in Oncidium and spurs in Habenaria (Figure 2-3). Despite the newer classification systems proposed, I follow that of Garay such as found in Pabst \& Dungs (1975, 1977), mainly due to its wide use in herbaria. Some valuable data, such on Habenaria itacolumia was taken from Hoehne (1940).

The area circled (Figure 1) Was carefully searched, and most of the distinct ecotones were taken into consideration. All areas were visually scanned, and even the most hard-to-reach places were visited. The subjectivity of the search was reduced by examination of all areas, even those which had an apparently small probability of containing orchids. 


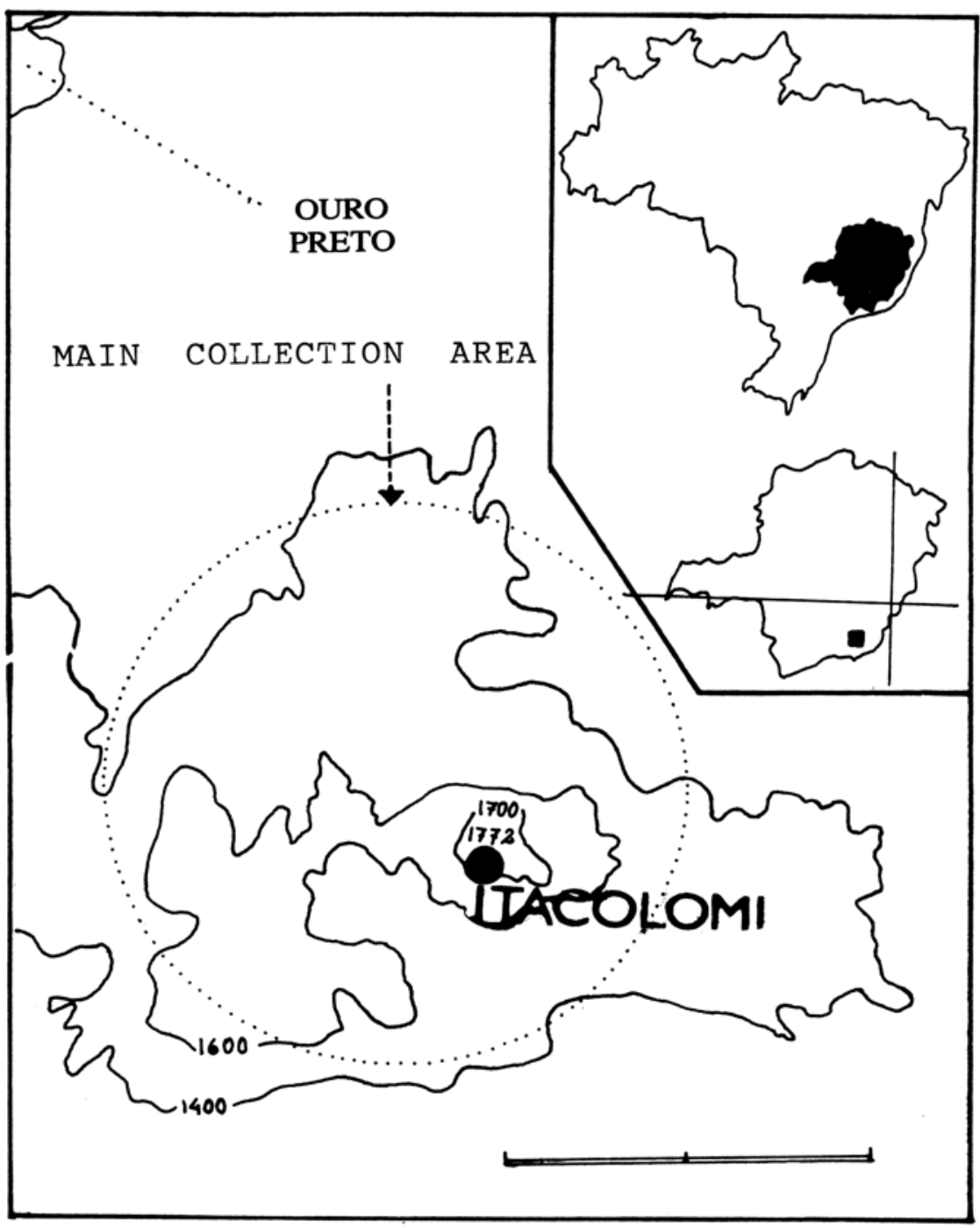

Figura 1: Location of collecting site (circle area) 


\section{Results}

This survey is preliminary in the sense that other species may be refound or discovered in the referred biota. The distribution of these species and their dependence upon the existing plant associations in the park is still being studied, but the data herein can already be useful for researchers concerned with the local flora, vegetation, and wildlife preservation (Table 1).

Since collections up to now have been sporadic, the present comparison has only relative value. Permanent quadrats had been established in the past, we could today detect most causes of the fluctuation in these orchid populations.

The taxa in the aggregate of Epidendrum ellipticum Graham are taxonomically critical. Separated by many botanists into species such as $E$. ellipticum Grah., E. denticulatum B. Rodr., E. xanthinum Lindl., or E. versicolor Hoehne, they have not yet been satisfactorily ellucidated as well defined species (Alves 1989a), Other critical taxa belong to the genera Anacheilium Hoffmannsegg, Oncidium Sweet, and the lythophytical group of the genus Laelia (sect. Parviflorae).

Sophronitis brevipedunculata was rediscovered on the main summit of Itacolomi mountain after many years of absence from local collections. Mainly for this reason only two samples were collected. The population of this species is very sparse and small. Epidendrum kueppelianum represents a new taxon for the park and probably a new species for the state of Minas Gerais as a whole. The species is not mentioned in available compendia as late as 1977 (Pabst \& Dungs 1977).

One famous taxon of the Itacolomi range is Itacolumia ulei Hoehne ( $\mathrm{Ha}$ benaria itacolumia Garay). This species was found on my first trip there in 1987 , a few meters from the base of the summit obelisk, but was not collected. I'nsterior field trips did not yield new findings.

Most orchid taxa in Itacolomi Park depend strictly upon their respective vegetation units, which provide specific and narrowly defined environmental conditions. Malaxis excavata is restricted to cushions of sphagnum on the partly shaded edges of "fumaroles" (deep narrow crevices with a constant updraft of cool, moist air). Dichaea cogniauxiana occurs only on the mossy trunks (never over $70 \mathrm{~cm}$ above the ground) of trees and tree-ferns on the edges of the "fumaroles". These woody stands physiognomically resemble gallery forests. They sharply border the "campo ruprestre" vegetation which surrounds them. D. cogniauxiana prefers the more horizontal branches, abounding more on trees with thicker, moss cove; ed baik. A hair-hygrometer reading on these branches leaps to $100 \%$, while $20 \mathrm{~cm}$ to either side only $60 \%$ is detected. These readings need to be complemented by corparable nocturnal measurements, but one may suppose that the moist updraft and dense vegetatisn: should prevent greater fluctuations of these daytime values. 
Table 1: List of the Orchidaceae of the Itacolomi State Park, Ouro Preto, Minas Gerais, Brazil. (Collected material only)

TAXON

SUBFAM, ORCHIDOIDEAE:

Habenaria caldensis Krzl.

Habenaria petalodes Lindl.

Habenaria rupicola $\mathrm{B}$. Rodr.

Habenaria umbraticola B. Rodr.

SUBFAM. NEOTTIOIDEAE:

Cleistes lepida (Rchb. f.) Schltr.

Cleistes macrantha (B. Rodr.) Schltr.

Cranichis nudilabia Pabst

Epistephium speciosum R. L. Rodr.

Pelexia longibracteata $\mathrm{Pabst}$

Prescottia glaziovana Cogn.

Prescottia montana B. Rodr.

SUBFAM. EPIDENDROIDEAE:

Anacheilium alemannioides (Hoehne) Pabst

Anacheilium vespum (Vell.) Pabst ex Dressler

Bifrenaria aureo-fulva (Hook.) Lindl.

Bifrenaria thyrianthina Rchb. f.

Bulbophyllum ipanemenis Hoehne

Bulbophyllum weddelli (Lindl.) Rchb. $\mathrm{f}$.

Dichaea cogniauxiana Schltr.

Encyclia oncidioides (Lindl.) Schltr.

Epidendrum ellipticum agg.

Epidendrum aquaticum Lindl.

Epidendrum kluepplianum Pabst.

Gomesa planifolia (Lindl.) Kl. \& Rchb. f.

Grobya galeata Lindl.

Koellensteinia tricolor (Lindl.) Rchb. f.

Laelia bradei Pabst

Laelia cinnabarina Batem.

Laelia flava Lindl.

Malaxis excavata (Lindl.) Kuntze

Oncidium batemannianum Parm.

Oncidim blanchettii Rchb. f.

Oncidim jonesianum Rchb. f.

Pleurothallis limae Porto \& Brade

Scuticaria hadwenii Hort. ex Hook.

Sophronitis brevipedunculata (Cogn.) Fowl.

Sophronitis mantiqueirae Fowl.

Splecklinia rupestris (Lindl.) F. Barros

Xylobium foveatum (Lindl.) Nichols

Zygopetalum mackayi Hook.

Zygopetalum triste B. Rodr.
MATERIAL

HERBARIA

MP 70

RA

JB, MP 69, 110

RA, MP 171

RB

OUPR

RB

JB

MP

MP 202

RA

RA

MP 225

MP 201

OUPR

RB

RB

RB

RB

RB

RA, JB

RA 257

OUPR

RB

RB

RA 258

RA

JB

RA

RA, MP RB, OUPR

RA

RA 263

RA, MP 85

MP 271

RA

MP 178

MP 139

MP, RA

MP

RA 261

RA 260, JB, MP

MP 82, RA 256

MP, RA

MP, RA

MP, RA

RA

JB

RA, JB

JB

RA, JB

MP 179

RA, JB

RA
RB, OUPR

RB

RB

RB

RB

RB

RB

OUPR

RB, OUPR

RB, OUPR

RB, OUPR

RB

OUPR

OUPR

OUPR

OUPR

OUPR

RB

OUPR

OUPR

Abbreviations: OUPR $=$ Herbario José Badini, RB $=$ Herbarium of Rio de Janeiro Botanical Garden. Numbers indicate numbered specimens. 


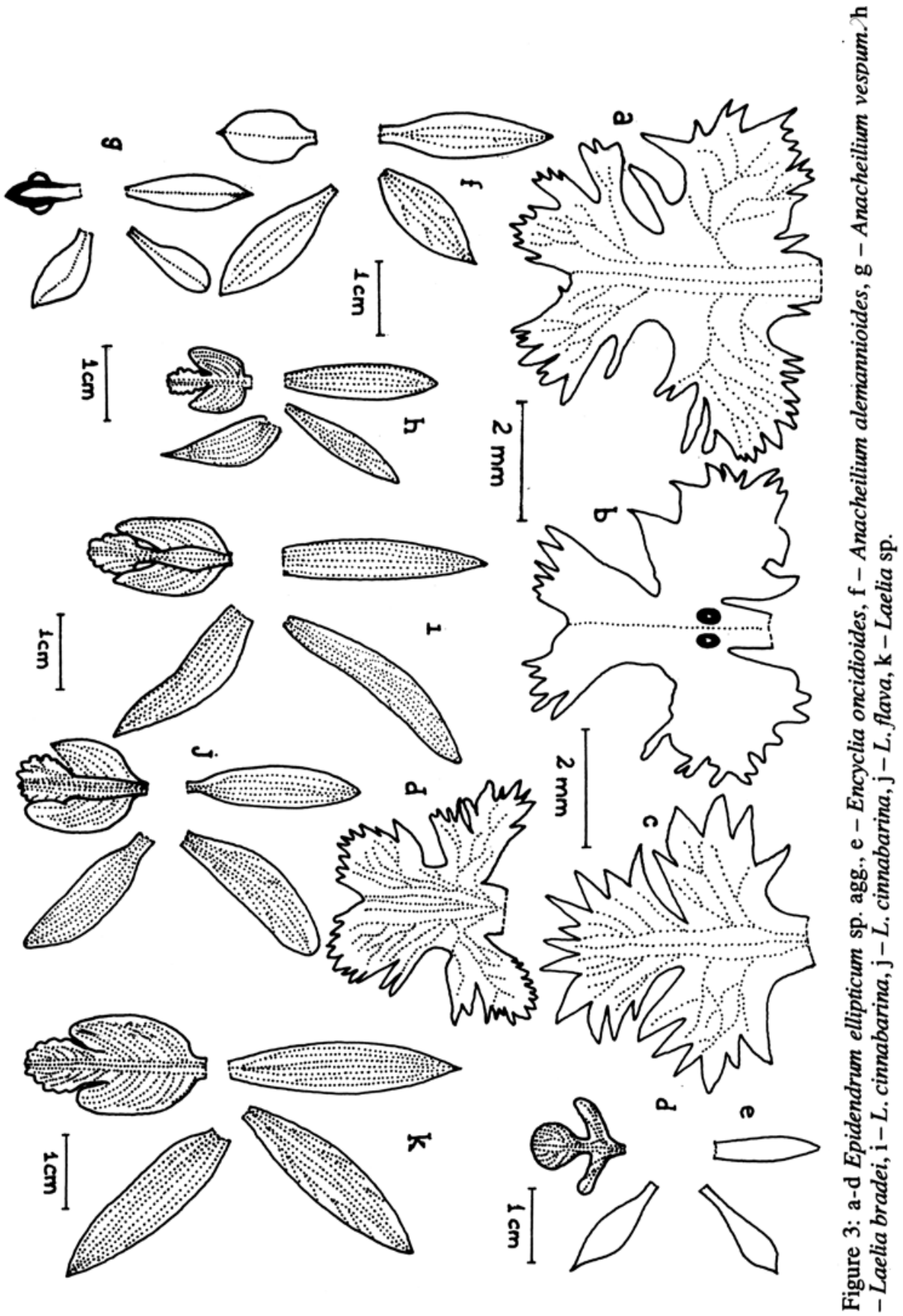




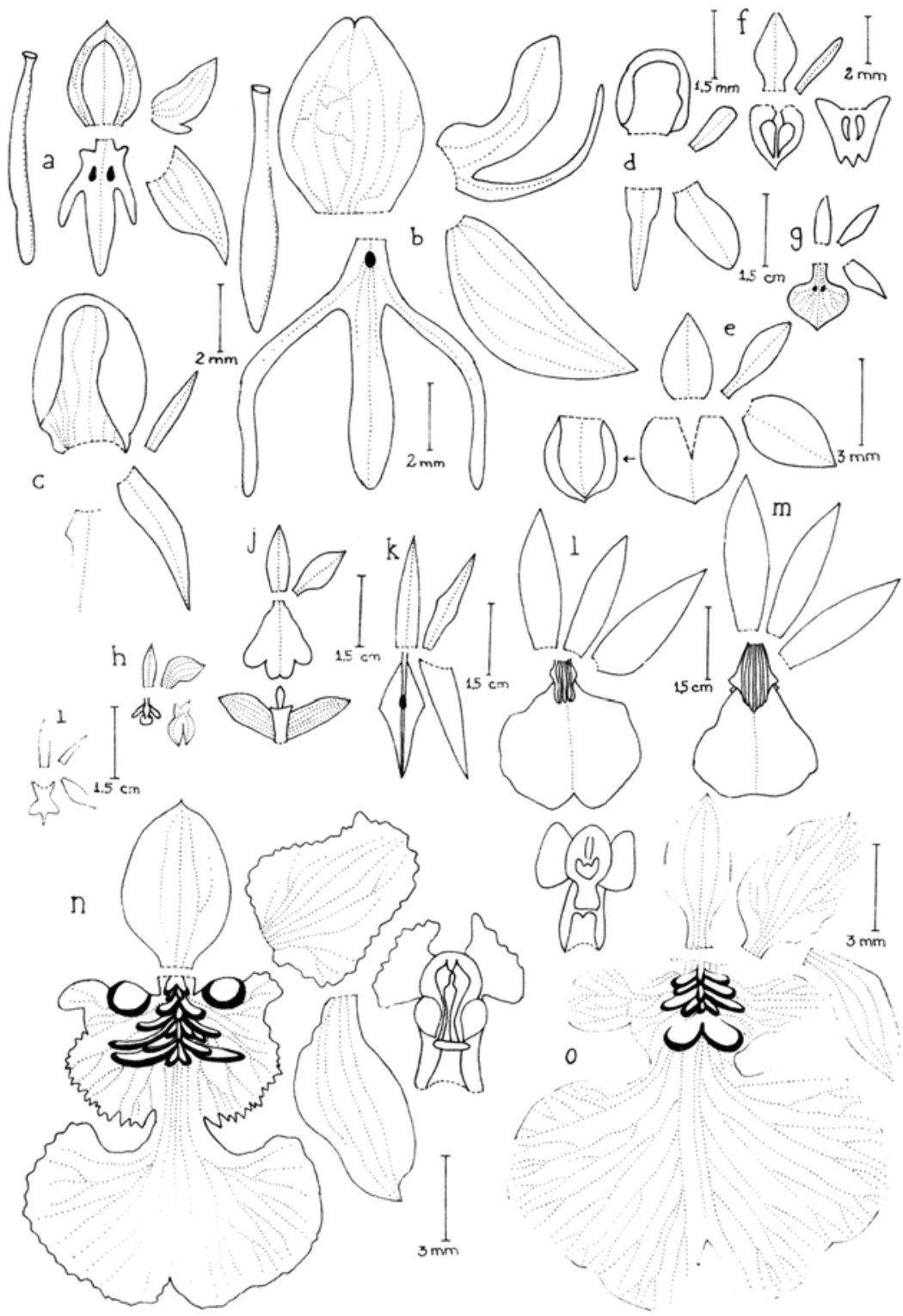

Figure 2: a - Habenaria umbraticola, $\mathrm{b}-H$. rupicola, $\mathrm{c}-$ Prescottia montana, $\mathrm{d}-P$. glaziovana, e-Cranichis nudilabia, 7 - Malaxis excavata, 9 - Epidendrum Klueppelianum, $\mathrm{h}$ - Grobya galeata, $\mathrm{i}$ - Epidendrum aquacticum, $\mathrm{j}-\mathrm{X}$ lobium foveatum, $\mathrm{k}$ - Bifrenaria aureo-fulva, l - Zygopetalum triste, m-Z. mackayi, n - Oncidium aff. batemannianum, o-Oncidium blancketti. 
In the open "campos rupestres" the herbaceous layer is dominated by subshrubs such as Microlicia and Lavoisiera of the Melastomataceae, accompanied by Xyris incana (Xyridaceae), Bulbostylis sp. (Cyperaceae), Eryngium paniculosum (Daucaceae), and Paepalanthus hilairei, P. spp. (Eriocaulaceae). Orchid species of Zygopetalum occur in these more open formations, as heliophytes. $Z$. triste and $Z$. mackayi both seem to require high air humidity and substrate hidrature. $Z$. triste is more abundant while $Z$. mackayi was apparently overcollected for commercial purposes.

Many of the species collected in the past by Jose Badini were not rediscovered in the field. Their disappearance is most probably due mainly to inadequate management of the park. Commercial overcollection seems quite innocent when compared with the destructive power of primitive farming techniques, such as slash-and-burn agriculture. The burnouts, or "queimadas" are still very frequently practiced by the local population. During my stays in the field I witnessed such absurd things as a forest fire provoked by irresponsible boy scouts. These seem to be the main causes of the (hopefully temporary) disappearance of such species as Sophronitis mantiqueirae, Scuticaria hadwenii and Habenaria itacolumia from the itacolomi State Park. Hopefully the species will be rediscovered in due time.

\section{Acknowledgements}

I wish to stress my profound gratitude to Grabiel Lacerda Troianelli for his kind assistance in the field work, to Jose Badini and Marcos Valeriano Peron for their loan of materials and comments, and to the Brazilian Council for the Development of Research (CNPq) for their support of my research.

\section{Bibliographic references}

ALVES, R. J. V. 1989a. Methods of floral analysis in species of the Brazilian Orchidaceae. Preslia, 62: (in press)

ALVES, R. J. V. 1989b. Floral morphology and distribution of the Epidendrum ellipticum complex (Orchidaceae) in Brazil. Preslia 62(1):25-30

HOEHNE, F. C. 1940. Flora Brasilica - Orchidaceas, vol. XII-I, p. 181-183; tab. 123; São Paulo

PABST, G. F. J. \& F. DUNGS. 1975. Orchidaceae brasilienses. vol. I. Berlin.

PABST, G.F.J. \& F. DUNGS. 1977 Orchidaceae brasilienses. vol. II. Berlin.

PERON,M. V. 1988. Levantamento florístico dos campos rupestres do Parque Estadual do Itacolomi. In: Resumos, Congresso Nacional de Botânica 39, Belém. 